\title{
小型 U-トラフの凍上被害に関する屋外実験
}

\author{
FIELD TESTS ON FROST HEAVING DAMAGE OF SMALL SIZED U-TROUGH
}

\author{
鈴木輝 之**山田利之** \\ By Teruyuki SUZUKI and Toshiyuki YAMADA
}

\begin{abstract}
The experiments on the mechanism of damage of relatively small sized concrete U-trough with ground freezing were made. For this purpose, 450 millimeter concrete U-troughs specified in JISA-5305 were experimentally set, and the collapsing force, deformation, and so on arise at the troughs in winter season were measured. Through this study, the following results were obtained. 1) The collapse of concrete U-trough occured after ground freezing mainly had origin in frost heaving. 2) Under a certain condition, the magnitude of frost heaving pressure acting on the trough was far over the destruction resistance of tested trough. 3) The effect of some countermeasures attempted in this study were evidently recognised.
\end{abstract}

Keywords : concrete U-trough, field test, frost heaving pressure, volcanic ash soil

\section{1.まえがき}

近年道路の整備が進みその付帯構造物の 1 つである排 水側溝は, 鉄筋コンクリート製のU 形トラフを用いて, 排水機能の向上と恒久化を計ることが多くなっている. また，農業土木の分野でも，用排水路として大小の既製 品トラフを用いることが非常に多くなっている.

このような状況のもとで，トラフが冬期間の地盤凍上 に伴う凍結土圧によって破壊されるという被害が見過ご せない問題となっている.

地盤の自然凍上による構造物の被害に関する工学的な 研究は, 道路や鉄道の凍上被害対策に関するものを中心 として多く行われてきており，その成果をまとめた本も 出版されている11. しかし, 自然の凍上が構造物に与える 被害は，きわめて多様な因子に支配されるので，1つの 具体的な構造物を対象とした研究の成果が, そのまま他 の構造物の被害対策を㭘討するうえで適用できるとは限 らない.

道路の側溝が地盤凍上によって被害を受けることは,

* 正会員 工博 北見工業大学助教授 土木工学科 （宁090 北見市公園町 165）

** 大成基礎設計 (株) 東北支社 (元 - 北見工業大学大学院生) (厂980 仙台市若林区新寺 $3-13-10)$
かなり以前から指摘されている2).しかし，その被害対策 に関する研究はこれまでほとんどみられず，最近になっ て, 被害の実態に関する調査がいくつかみられる程度で ある ${ }^{3), 4)}$. 一方, 類似の問題として, 農業用水などで用い られている比較的大型の用水路側壁の凍上被害に関する 研究は行われており, 対策工法も示されている. しかし, この研究の中でも, 小型水路の凍上被害については対象 とはならず, 状況に応じて対応する必要のあることだけ が述べられている5),6).

本研究は, JIS A 5305 に定められる比較的小型の既 製コンクリートトラフの凍上被害を対象としたものであ る. 周辺地盤の凍結に伴うトラフの被害で問題となるの は, 全体の持上がりと側壁に加わる凍結土圧によって押 しつぶされることの 2 つである.この 2 つの被害は凍上 力あるいは変位に鉛直方向と水平方向の 2 つの成分が含 まれることによるのであり，独立した原因によるもので はない.このうちトラフの持上がりについては, 周辺地 盤の融解とともに元のレベルに戻る傾向が強く，また卜 ラフ自体の破壊を招くものでもない. 一方, 側壁に加わ る凍結土圧の水平方向成分によって押しつぶされた場合 には，トラフ自体が破壊してしまうので，水路としての 被害も大きいものとなる.

いま, 道路および大型水路の凍上現象を念頭において, 
本研究で扱っている比較的小型のコンクリートトラフの 凍上問題の特性を挙げると，次のようになろう。

1) 凍結線の形状が水平にならないため, 加わる力や 変位の成分が複雑になる。

2）トラフが押しつぶされて破壊することが問題なの であるから，側壁に加わる凍結土圧の大きさをとらえる 必要がある。

3 ）一般に, 冬期間は積雪に覆われる構造物であるの で,この効果の考慮も必要である.

4) トラフの深さはたかだか $60 \mathrm{~cm}$ であるから, 寒さ の厳しい地域では, 凍結深さがトラフの媣さ以上になる 場合がある.

本研究では, 呼び名 $450 \mathrm{~mm}$ (JIS A 5305) のコンク リートトラフを, 埋戻し材料や背面傾斜などの条件をい くつかに変えて試験設置し, 冬期間における 1 )気温およ び背面土中の温度， 2 ) 側壁に加わる凍結土圧， 3 ) 側壁 上端部での内寸法の縮み, 4 ) トラフの持上がり量の 4 項 目の測定を行った. 実験は昭和 60 年度より開始し, 現在 も継続している．本論文中では，これらの測定結果に基 づき，主として次のような点について検討を加え，その 内容を明らかにしている。

1) 側壁背面土中への凍結進入状況と側壁に加わる凍 結土圧の発生機構.

2 ）気温変化に対応した凍結土圧およびトラフ縮み量 の短期的経時変化とその機構.

3 ）凍結土圧およびトラフ変形量のシーズンを通した 長期的変化特性とそれらの相対的関係.

4 ) 凍結土圧およびトラフ変形量の長期的変化に及ぼ す裏込め材料, 背面地形などの設置条件の影響.

\section{2. 実験}

\section{（1）試験トラフの設置定規と埋戻し材料}

JIS A 5305 に定める鉄筋コンクリート製 U 形トラフ を, 北見工業大学構内に試験設置し, 昭和 60 年度 62 年 度の 3 シーズンにわたって各種の測定を行った結果を示 している. 裏込め材料などの設置条件は年度によって少 しずつ異なるが 62 年度の場合を例として, トラフの設㯰 状況を図一 1 に示す。 また, 設置定規を図一 2 に示す.

設置場所は, 南西向きの日当りの良い人工造成地の斜 面の下である. 図一 1 に示すように, この場所の地表面 は風化の程度が比較的小さいと思われる火山灰で覆われ ているが，地表面から浅いところに造成前の地表面との 境界がある. 本文中では現地表面の土を現地土, 旧地山 の土を旧地山土とおのおのよんでいる. 地下水位は確認 されていないが, この場所より $30 \mathrm{~m}$ ほど離れたところ に本学の取水井戸があり, その井戸のボーリング記録に よれば, 地下水の梁さは平坦地表面より $19.6 \mathrm{~m}$ となっ
ている.このように，この付近の地下水位はかなり低い ことは間違いなく, 地盤が凍上するときの地下水面から の水分供給はないものと思われる，ただし，少量である が旧地山との境界に沿っていると思われるのり面側から の浸透水の存在が, トラフ設置の段階で認められた。 な お, No. 21〜25のトラフは, 両背面が平坦な条件を作り 出すように設置したものである.

設置したトラフは，4～5個ずつのスパンに分け，各 スパンごとに裏込め材料の種類などの設置条件を変えて いる. 図一 2 中に用いた裏込め材料の種類および断熱材 の設置方法を示し, 表一 1 に設置現場の土と裏込め材と して用いた土の性質を示している.これらの中で，火山

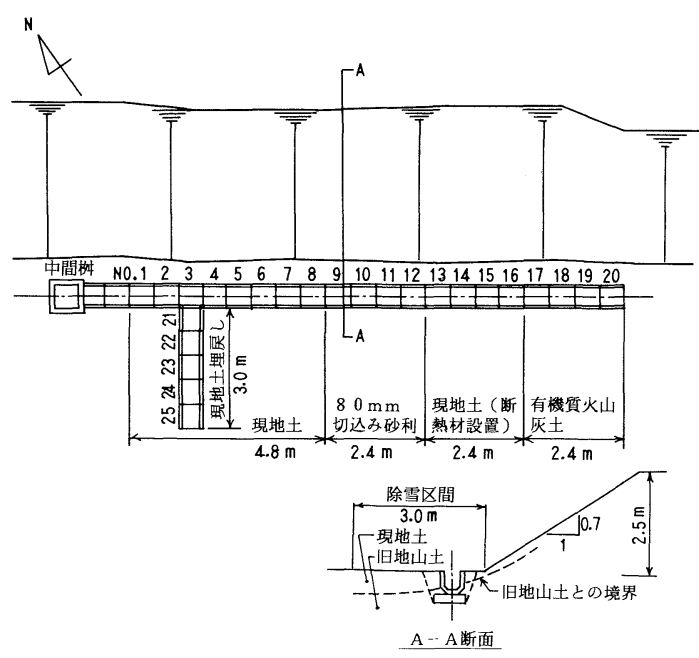

図-1＼cjkstart試験トラフの設置状況（昭和 62 年度）

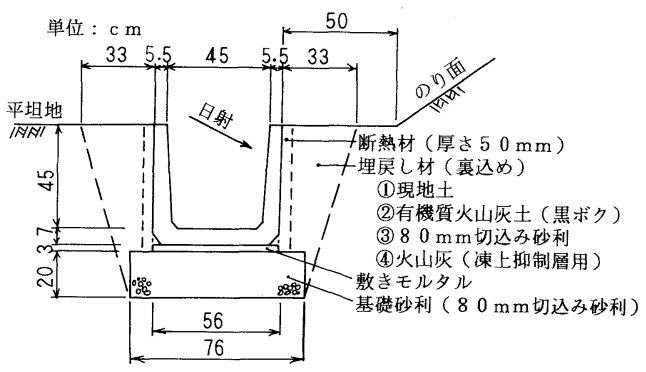

図一2 設置定規と背面処理の種類

\section{表一 1 試験トラフ周辺土の性質}

\begin{tabular}{|c|c|c|c|c|c|}
\hline & 現地土 & 火山圧 & 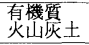 & 旧地山土 \\
\hline \multirow{2}{*}{\multicolumn{2}{|c|}{$\begin{array}{l}\text { 比 } \quad \text { 重 } \\
\text { シルト以下重量比 (\%) }\end{array}$}} & 2.53 & 2. 49 & 2.48 & 2. 59 \\
\hline & & 33.0 & 23.0 & 56.0 & 51.0 \\
\hline \multirow{2}{*}{$\begin{array}{l}\text { 締固め } \\
\text { 特珄 }\end{array}$} & Wopt $(\%)$ & 24.3 & 25.6 & 35.5 & 23.8 \\
\hline & $\rho \operatorname{dmax}\left(\mathrm{tf} / \mathrm{m}^{3}\right)$ & 1. 46 & 1. 37 & 1.23 & 1. 52 \\
\hline \multirow{2}{*}{$\begin{array}{r}\text { *凍上 } \\
\text { 特性 }\end{array}$} & 凍上率 (\%) & 25.4 & 3.0 & 44.0 & 31.3 \\
\hline & 凍結様式 & 微細霜降状 & $\begin{array}{l}\text { コンクリ } \\
\text { ート状 }\end{array}$ & 霜柱状 & 霜柱状 \\
\hline
\end{tabular}


灰は北見地方で道路の凍上抑制層として用いられている 難凍上性の材料であり, 有機質火山灰土は有機成分を含 む火山灰地の表土で，あえて凍上性の強い材料で埋戻し てみたものである。このように同じ火山灰質土でも凍上 性が大きく異なるのはシルト以下重量比の違いによるも のと思われる. また, 断熱材は比較的軟らかい厚さ $5 \mathrm{~cm}$ の発泡スチロール板で, このときの埋戻しは現地土で 行っている.

\section{（2）測 定方法}

実験は図一 1 に示す除雪範囲を常に除雪し，トラフ背 面土中への凍結浸入に対する積雪の影響をなくした状態 で行っている. 測定項目と方法は以下のとおりである.

a) 温 度 気温, 背面土中およびトラフ表面につ いて, 合計 30 点の温度センサー ( $\mathrm{c}-\mathrm{c}$ 熱電対) を配置し, 1 時間間隔で自動計測した。

b ）側壁に加わる凍結土圧 一部のトラフにおいて は図一 3 に示す状況で, ロードセルに加わる荷重を 1 時 間間隔で自動計測した。 なおこのロードセルではー $25^{\circ} \mathrm{C}$ 〜 $+20^{\circ} \mathrm{C}$ の間で有為なゼロドリフトは認められなかっ た.

この方法で測定される荷重は, 側壁に加わる凍結土圧 の水平成分の一部である，厳密にみれば，側壁は背面の 凍土と凍着して一体化するので, 加わる力の成分はかな り複雑になっていると思われる. 図一 3 の方法では, 卜 ラフを押しつぶす原因となる凍結土圧の成分を，巨視的 に測定していることになると考えられる。このような観 点からすれば多少厳密さを欠くことになるが, 本文中で

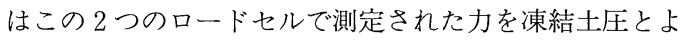
んで用いている.

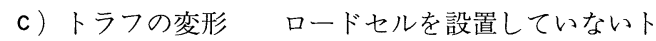
ラフ（図一 3 に示す底盤の切り目を入れていない）では， 側壁上端部での間隔の変化をノギスによって 1 日に 1 回 測定した。また，側壁上端部に変位計を挟み，側壁間隔 の変化を 1 時間ごとに自動計測することも一部で行っ た．本文中では，この変化量のことをトラフの“縮み量” とよんで用いている。

d）トラフの持上がり量＼cjkstart設置したすべてのトラフ について，両側壁の天端の持上がり量をレベルによって 1 週間に 1 度測定した.

\section{（3）実験シーズンの気温および凍結深さ}

図一 4 に実験を行った 60 年〜 62 年の 3 シーズンの凍 結指数と凍結深さを示す．日平均気温のマイナスになる 日は 11 月中旬から翌年の 3 月末にかけて現われた。これ に対して地盤の凍結は，11月末から入り始めて，2月末 まで進行していきその後後退している.

また， 61 年度の凍結深さは 3 か所での值を示してい る.この中で，のり面は除雪を行っておらず，平坦地は

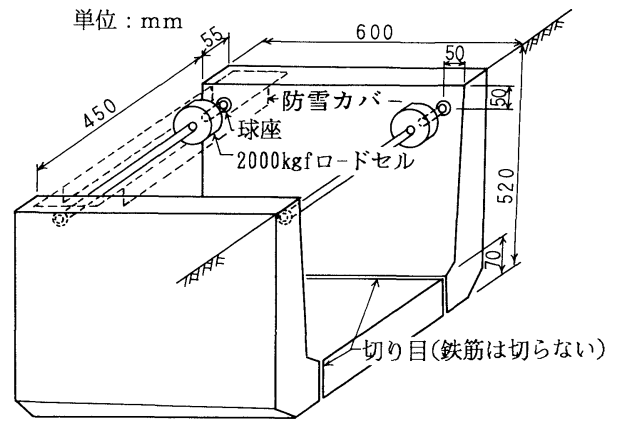

図一３凍結土圧の測定方法

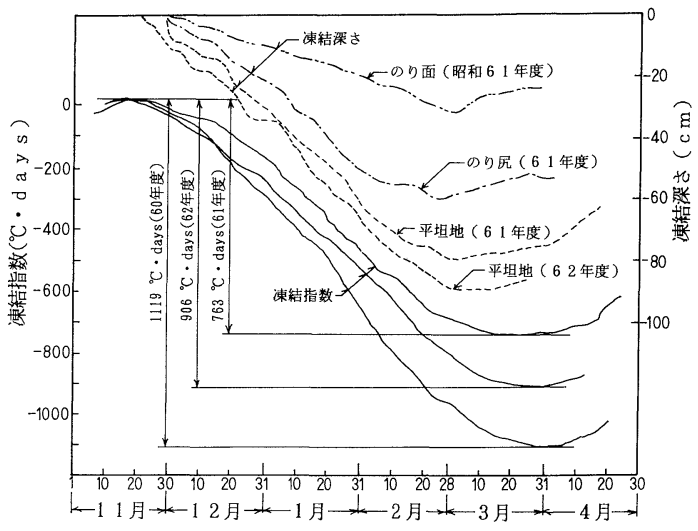

図一4 測定シーズンの凍結指数と凍結深さ

除雪している．また，のり尻は除雪区域の境界に当たっ ている.このように積雪条件さらに地形条件の違いに よって，凍結深さは大きく異なることがわかる.

\section{3．実験結果および考察}

\section{（1）トラフ背面土中への凍結浸入}

図一 5 に現地土で埋戻したトラフの背面土中の $0{ }^{\circ} \mathrm{C}$ 線の推移を示している. これらの曲線は, 図中に示す温 度測定点の值から内挿法で求めたものであり，測定は， 昭和 60 年度と 61 年度に分けて行っている.この $0{ }^{\circ} \mathrm{C}$ 線 と凍結線とは厳密には少し異なることが知られている が，実用的には同じとみなして差し支えない7).ここでは 実測された $0{ }^{\circ} \mathrm{C}$ 線を凍結線として考察を進める.

凍上は凍土と末凍土の境界すなわち凍結線付近で発生 し，その力や変位の方向は凍結線に垂直となる.

このほかに地盤の凍結によって発生する力としては, 既存の土中水の凍結澎張によるもの，さらに二次凍上 ${ }^{8)}$ あるいは二次膨張" ${ }^{9}$ とよばれる現象によるものなどが認 められている。また実際の構造物に加わる力すなわち凍 結土圧は既凍結部分を介して伝えられるのであるから， 


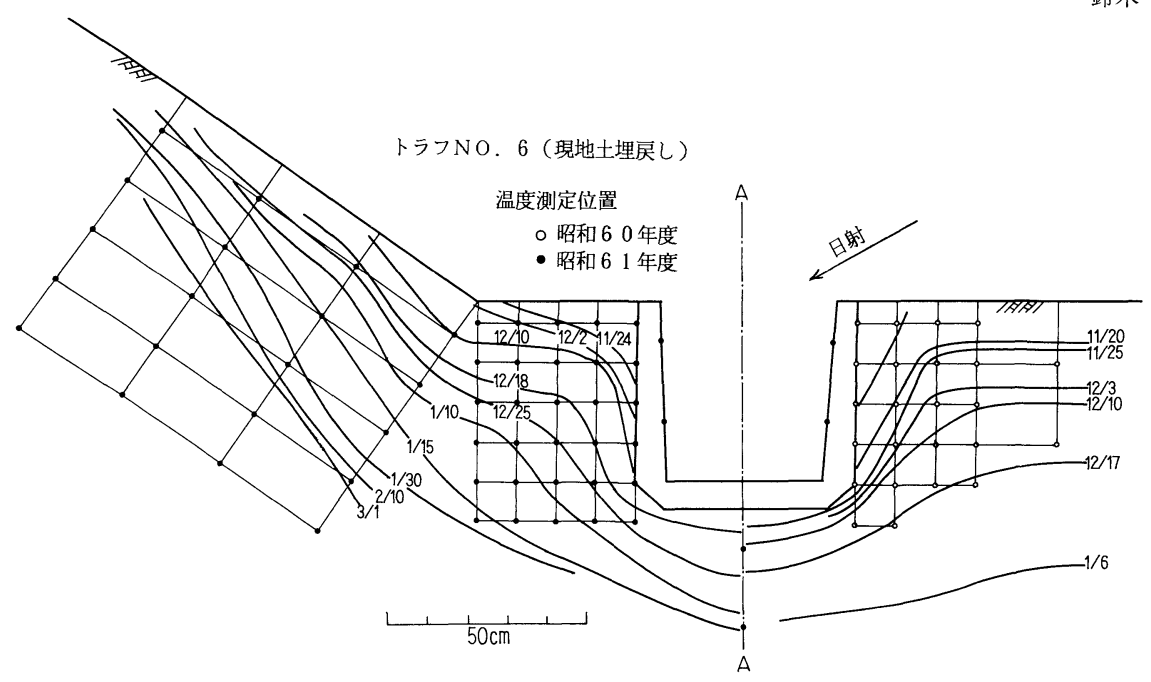

図－5 トラフ背面土中への凍結線の進入状況

凍上の熱膨張特性やクリープ特性などもその力に大きく 影響してくる.このように地盤の凍結に伴って構造物に 加わる凍結土圧の大きさは, 非常に複雑な因子の影響を 受けるが, その力の主な発生源は, 凍結線付近で発生す る凍上力によると考えてよいであろう.

以上の考え方を前提とすれば，図一 5 から次のことが いえる.

a) トラフ背面土中では, 凍結線が傾いて入っていく ために凍上力あるいは凍上変位に水平方向成分が現わ れ，これがトラフを押しつぶす原因になっていると思わ れる。

b ）トラフ背面がのりになっている場合は，凍結浸入 の深さにかかわらず凍結線は傾き，凍上力の水平成分が 現われる。

c）一方, 背面が平坦な場合には, 凍結が深く入って くると, 凍結線は水平に近くなり, 凍上力の水平成分は 小さくなると考えられる.

これらの内容は，次節以後に示す凍結土圧や縮み量の 実測結果に現われてくる.

\section{（2）凍結土圧および縮み量の短期的経時変化}

図一 3 の方法で測定された凍結土圧, ロードセルを挟 んでいないトラフの側壁上端部での縮み量, および温度 の 3 つの経時変化について, 昭和 61 年度の測定結果の例 を図一6に示す。また，図一 6 の測定が行われた期間に おける凍結線の移動範囲を図一7に示寸.

まず温度についてみると, 気温は時期にかかわりなく

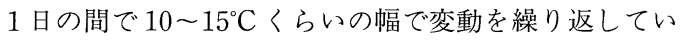
る. また直射日光が当たるトラフ表面の温度（測点 No. 25）は真冬日であっても一時的に $+10^{\circ} \mathrm{C}$ 前後まで上昇し
ている.この表面温度の上昇に対応して背面土と接して いる面の温度 (測点 No. 2) も一時的にプラスの温度にな ることがわかる.

このような日々の温度変化に対応して, 凍結土圧およ び縮み量ともに 1 日の間で大きく変動する.たとえば, 凍結進入初期（図一6 (a)）では，凍結土圧はピークが 400～600 kgf となるのに対して，200～500 kgfくらいの 幅で変動している，一方，凍結が深く進入し大きな凍結 土圧が加わる $1 \sim 2$ 月（図一 $6(\mathrm{~b}),(\mathrm{c})$ ) では, ピー ク值が 3000 4 $000 \mathrm{kgf}$ くらいまで上昇するが，変動幅

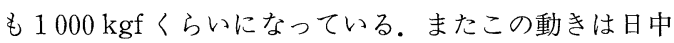
の気温の上昇とともに凍結土圧あるいは縮み量は増加し ていき，夕方にかけての気温の下降とともに，凍結土圧 あるいは縮み量が減少している。このように外気温の変 化に刻々と対応した形の凍結土圧や縮み量の変化に影響 する因子としては，

1 ) 気温変化に伴う凍結線での凍上発生量の変化

2 ) 凍土の熱膨張・収縮

3 ) 凍土のクリープによる応力緩和

などが考えられる，凍結初期においては凍上部分が薄い ために凍結線付近の温度が気温変化の影響を受けやすい から，凍結土圧の変動をもたらす因子として上記 1 )が 強く働いていると思われる. 一方, 凍結が深く入った時 点では凍結線における凍上の発生が気温の変化に対応し ているとは考えにくい，なぜならば，気温の変化が凍結 線における熱的バランスに影響してくるまでにはかなり の時間的な遅れがあるはずである，気温変化の影響を時 間的な遅れを伴わずに受けるのは，地表面に近い部分の 凍土のはずであり，この部分の凍土に作用する上記 2 ), 
3 )の因子が, 図一 6 に示すような凍上力や縮み量の変動 の主因になっているであろうことは推察される。

（3）凍結土圧, 縮み量および持上がり量の長期的変 化とそれらの相対的関係

前節の図一 6 に示したように，凍結土圧や縮み量は 1 日の間でも気温の変化に対応して刻々と変化する。いま これらの変化をシーズンを通して長期的にみるために, 図一6の実験における全データについて，1日の間での

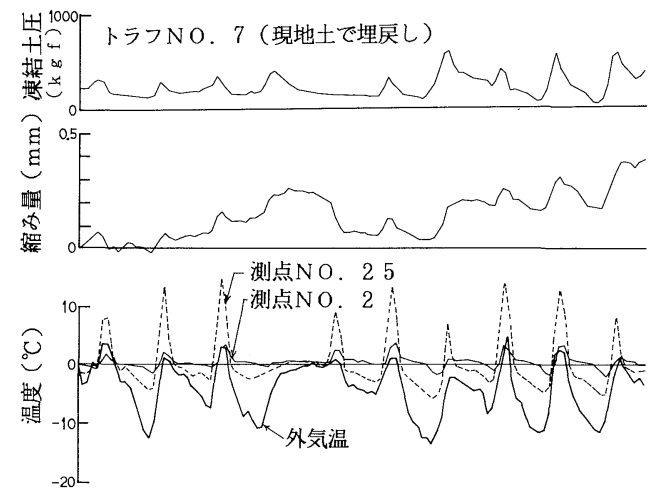

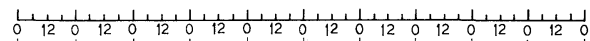
$+12 / 1+12 / 2+12 / 3+12 / 4+12 / 5+12 / 6+412 / 7+12 / 8+12 / 9+1210+$

(a) 12 月 1 日 $~ 12$ 月 10 日

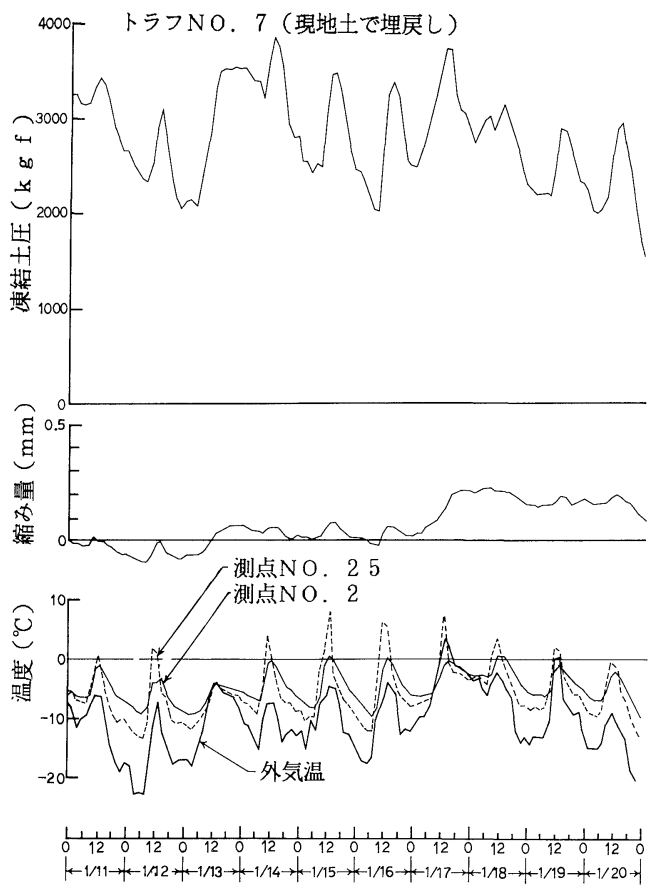

(b) 1 月 11 日 $~ 1$ 月 20 日
凍結土圧の最大值（日最大凍結土圧）と最小値（日最小 凍結土圧）をプロットすると図一8が得られる。また同 図中にノギスで測定した縮み量とレベルで測定した持上 がり量も併記している．四からわかるように，大きな凍 結土圧は，ロードセルを挟んでいないトラフで縮みがど んどん進行する時期に発生しており, 縮みがピークに達 しその進行が止まると同時に急速に低下している.

シーズンを通した凍結土圧や縮み量の大局的な変化は 凍結線において発生する凍上力あるいは変位を反映して いると考之られる，すなわち，前出の図一6に示す気温 変化に刻々と対応する凍結土圧や縮み量の短期的な変動 とは異なったメカニズムによるものと考えられる。縮み が進んでいるということは，凍上が発生していることを 示し，この縮みをロードセルを挟むことによって拘束す ると大きな凍結土圧が加わる．凍結線で発生する凍上力 や変位は，既凍結部を介して側壁に伝えられる．このと き凍土はクリープ変形の大きい材料であるから ${ }^{10)}$ ，厳寒 期に凍結線で涷上がどんどん発生している状況では, ト ラフの縮みや大きな凍結土圧の発生がみられるが，寒さ が緩んで涷上が収まると，凍土のクリープの影響が卓越 することによって凍結土圧は急速に緩和されると理解さ れる.また，トラフの縮みはかなりの部分は元に戻るが, この戻りは, 凍結土圧の緩和よりもかなり遅れて生じて いる。これは, 縮みが戻るためには, 背面凍土のある程 度の融解が必要なためと思われる。
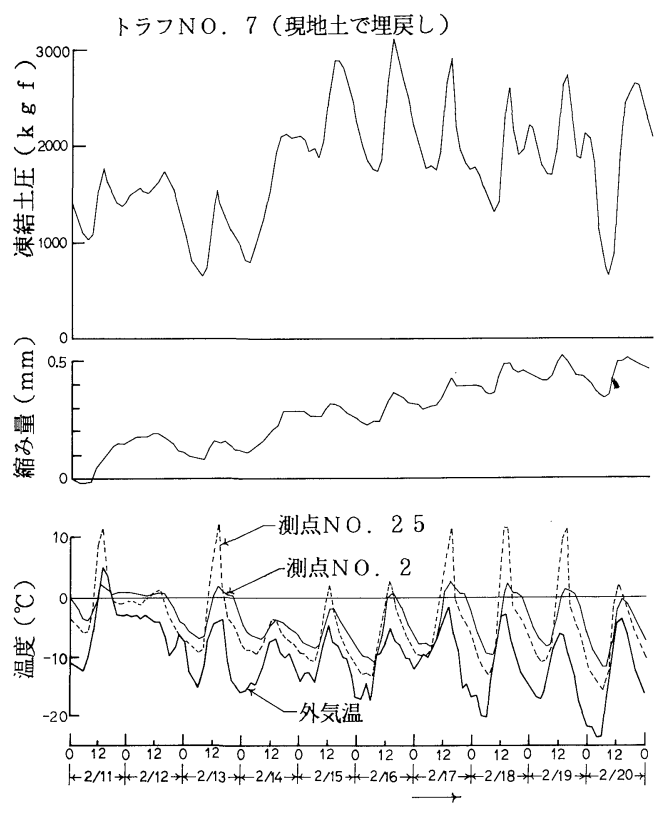

(c) 2 月 11 日 $~ 2$ 月 20 日

図一6 凍結土圧, 縮み量, および温度の短期的経時変化（昭和 61 年度） 


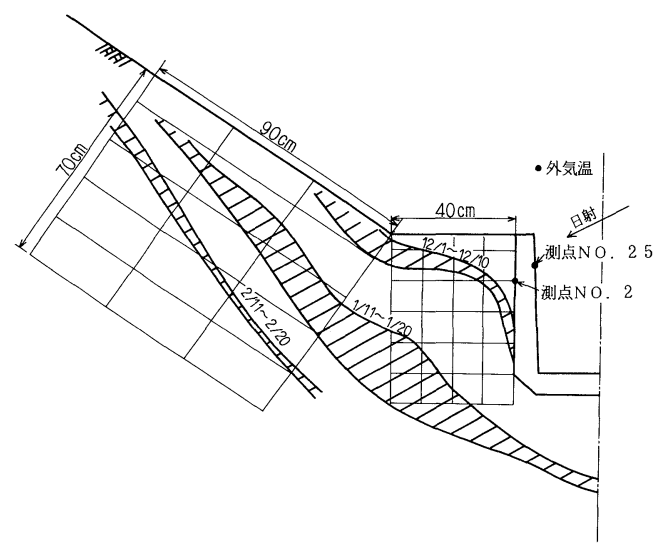

図一7 図一 6 の測定期間における凍結線の变化

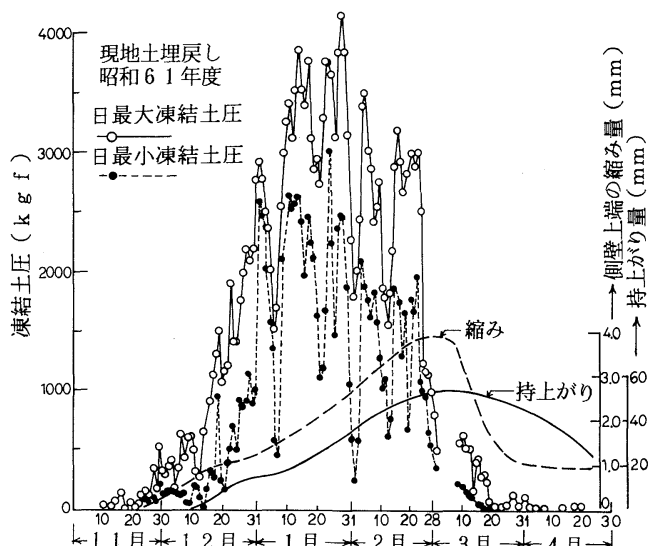

図一8 凍結土圧, 縮み量，および持上がり量の相対的関係 (昭和 61 年度)

一方，持上がり量に注目してみると，この進行は縮み 量の発生と類似している. 1つ異なる点は，元のレベル に戻っていく時期が，縮みの戻りよりもさらに遅れてい ることである．これは，トラフの縮みが主として側壁背 面部分の土の凍上に起因しているのに対して，持上がり は，トラフ底盤の下の土の凍上によっているためと思わ れる．気温変化の影響は側壁背面よりも下部の方が小さ いはずであり，春期の融解も下部の方が遅れると考えら れる。

凍上によって発生する力を調べる実験はかなり以前か ら行われており ${ }^{11)}$ ，最近では地盤の凍上力や凍上量を定 量的に予測する努力もなされている ${ }^{12), 13)}$. しかし, トラフ のような構造物に加わる凍結土圧となると，凍上によっ て発生する力および変形を伝える凍土の挙動，さらに未 凍土の圧縮性までも考慮しなければならない14)。このよ うに凍結土圧を支配する因子はきわめて複雑であり，こ

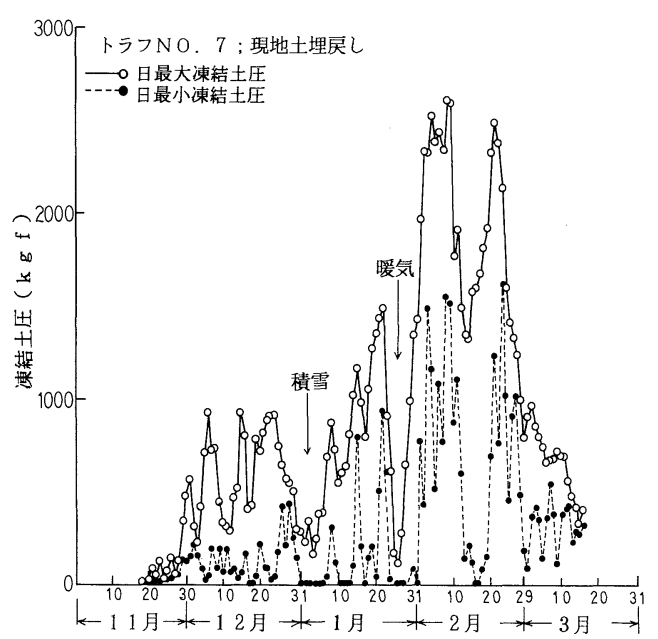

（a）現地土で埋戻した場合

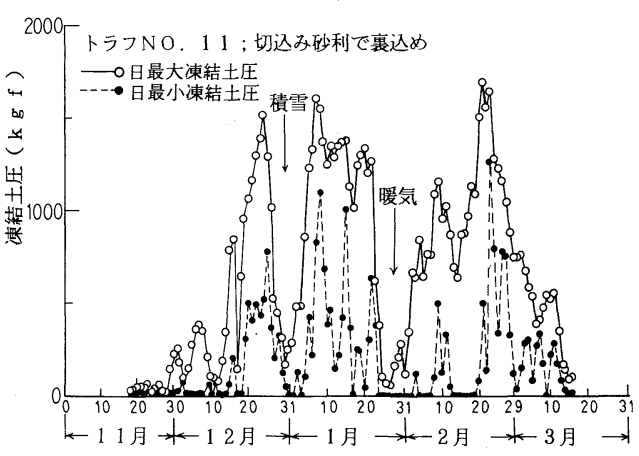

（b）切込み砂利で裏込めした場合

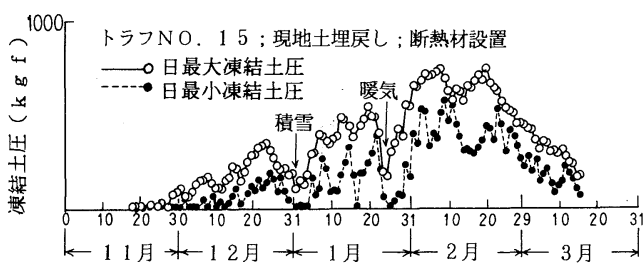

（c）現地土で埋戻し，断熱材を設置した場合

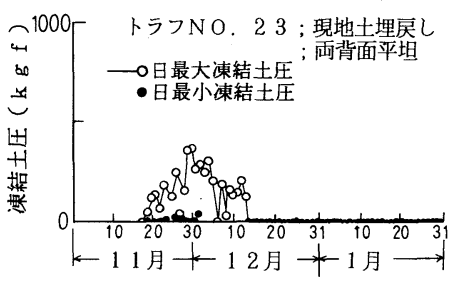

（d）現地土で埋杘し，両背面が平坦な場合

図一9 日最大・最小凍結土圧の変化（昭和 62 年度） 
れらのより正確な評価は今後の研究に待つところが多 い.

\section{（4）凍結土圧と縮み量の長期的変化に及ぼすトラフ 設置条件の影響}

前出の図一6で示した凍結土圧や縮み量の短期的ある いは長期的な変化は，裏込め材料や背面形状などの設置 条件によって異なってくる. 図一 9 は, 昭和 62 年度の実 験（図一 1 参照）において測定された日最大・最小凍結 土圧を，設置条件ごとに示したものである，ただし有機 質火山灰土で埋戻したケースでは凍結土圧の測定は行っ ていない。これらの図から次のことがいえる。

a) シーズンを通して，最大凍結土圧は現地土で埋戻 したトラフで $2610 \mathrm{kgf}$, 切込み砂利で裏込めしたトラフ

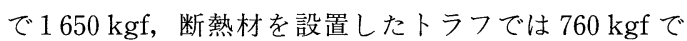
あった。このように切込み砂利で裏込めしたり断熱材を 入れたりすることの効果は明らかに認められる。

b ）非常に大きな力が加わっている時期でも, 地表が 一時的に雪に覆われたり暖気がきたりすることによって 凍結土圧はゼロもしくはそれに近くなる。

c）両背面の表面が平坦な場合（図一9 (d)) は，凍 結の浸入が始まる初期段階の 11 月下旬から 12 月初めに かけて小さな凍結土圧が発生するが, その後, 凍結深さ が大きくなった時期には力はゼロになっている.

図一9に示す凍結土圧を測定したトラフとおの扔の同 じ条件で設置し，かつロードセルを挟んでいない 3 個ず

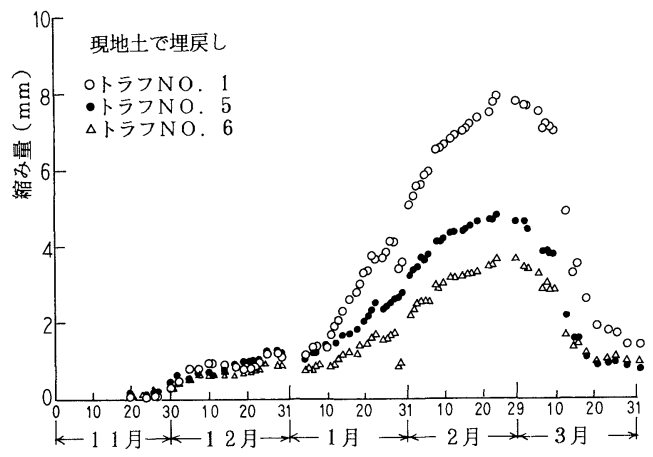

（a）現地土で埋戻した場合

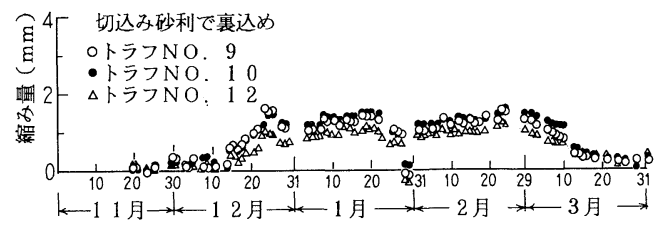

（b）切込み砂利で裏込めした場合
つのトラフについて，側壁上端部での間隔の縮み量を， ノギスによって 1 日に 1 回ずつ測定した結果が図一10 である，図一 9 に示す凍結土圧は，トラフの縮みを拘束 したときに発生するものであり，一般に用いられる設置 条件下では，図一10に示すような縮みが発生する。

前出の図一 8 で述べたように，図一 9 の凍結土圧の長 期的変化と図一10の縮み量の長期的変化とはある程度 の対応性をもつ。ここで, 凍結土圧と縮み量の両面から, 切込み砂利による裏込めと断熱材設置の効果を調べてみ る.上記ａ）で述べたように，凍結土圧の軽減における切 込み砂利や断熱材の効果は明らかに認められるが，相対 的には断熱材の方が効果が大きいようである. 一方, 図 -10の縮み量でみると, 現地土で埋戻した場合の最大縮 み量が平均 $5.3 \mathrm{~mm}$ であるのに対し，切込み砂利や断熱 材を入れた場合はおのおの $1.3 \mathrm{~mm}$ と $1.5 \mathrm{~mm}$ であり, 約 $1 / 4$ 程度に減少している。

トラフの凍上被害は凍結土圧の大きさよりも縮み量が どの程度発生し，さらにそれが経年的にどのように累積 されていくかによって見積もられるべきものと考えられ る.この点からすれば, 今回の実験の範囲では切込み砂

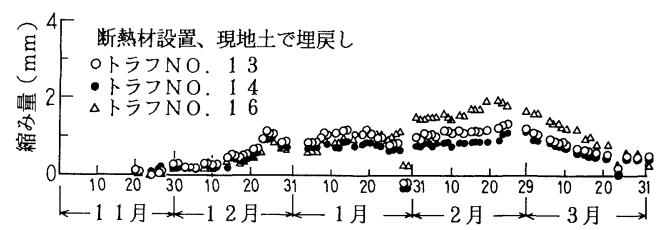

（c）現地土で埋帍し，断熱材を設置した場合

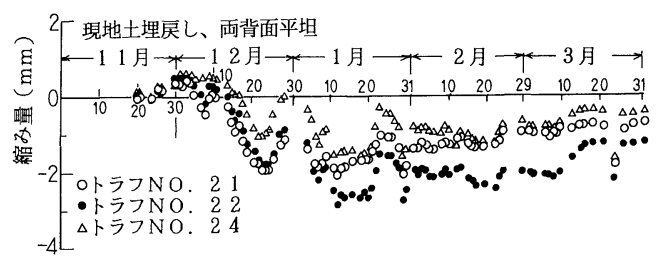

（d）現地土で埋戻し, 両背面が平坦な場合

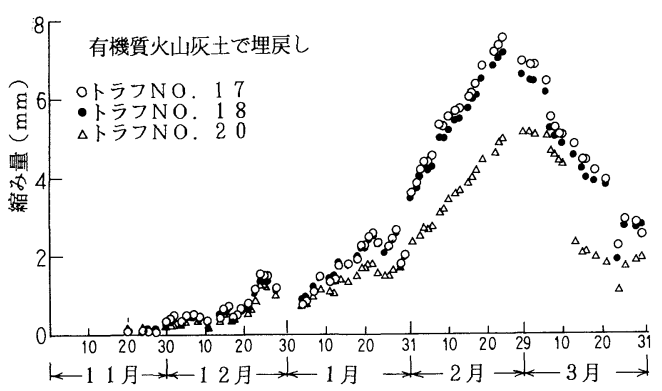

（e）有機質火山灰土で埋戻した場合

図-10 側壁上端部での縮み量の変化（昭和 62 年度） 
利による裏込めと，断熱材の設置は同程度の効果が認め られたといえよう。

次に，背面にのりがある場合（図一10(a)）と，両背 面ともに平坦地の場合（図一10 (d)）を比較してみる. この両者の違いは図一 9 ( a )，（d）に示す凍結土圧の大 きさにも明瞭に現われているが，縮み量においても大き な違いがみられる。この違いは，前出の図一 5 で述べた 凍結線の入り方によるところが大きいと思われる。 しか し，両背面が平坦地の場合には，凍結が深くなるとトラ フは縮むのでなく逆に広がっており，この広がりを凍結 線の入り方から説明することはできない. 原因としては， トラフ底盤下の土（旧地山土）が背面土（現地土）より も凍上性が大きい（表一 1) という地盤条件などが考え られる。

\section{表一2 凍結土圧, 縮み量, および持上がり量の最大値}

\begin{tabular}{|c|c|c|c|c|}
\hline & 裏込め材料 & $\begin{array}{l}\text { 最大凍結土 } \\
\text { 圧 }(\mathrm{kgf})\end{array}$ & $\begin{array}{l}\text { *最大縮 } \\
\text { み量 }(\mathrm{mm})\end{array}$ & $\begin{array}{l}\text { *最大持 } \\
\text { 上 }(\mathrm{mm})\end{array}$ \\
\hline \multirow{4}{*}{60 年度 } & 現地土（基礎砂利なし） & & 7.0 & 91 \\
\hline & 現地土 & $※ 2520$ & 9.8 & 42 \\
\hline & 火山灰 & & 4. 1 & 44 \\
\hline & $80 \mathrm{~mm}$ 切込み砂利 & ※ 800 & 1. 9 & 68 \\
\hline \multirow{3}{*}{61 年度 } & 現地土 & 4210 & 4. 2 & 59 \\
\hline & 現地土（日射遮断） & 3100 & 4. 7 & 54 \\
\hline & 有耭質火山灰 & & 3.2 & 42 \\
\hline \multirow{5}{*}{62 年度 } & 現地土 & 2610 & 5. 3 & 74 \\
\hline & 現地土（断熱材設置） & 760 & 1. 5 & 38 \\
\hline & $\begin{array}{r}\text { 現地土 (雨背面平坦) } \\
\text { (基砤砂利な) }\end{array}$ & 370. & 0.5 & 85 \\
\hline & $80 \mathrm{~mm}$ 切込み砂利 & 1650 & 1. 2 & 38 \\
\hline & 有機質火山灰 & & 6.4 & 62 \\
\hline
\end{tabular}

表一 2 に各実験を通して得られた凍結土圧，縮み量， および持上がり量のシーズンを通しての最大值を示す。 これらの結果からもわかるように, 難凍上性の材料で裏 込めをしたり，断熱材を設置することの効果は明らかに 認められる。実験に用いたトラフの製造工場での実験に よれば，このトラフ側壁の上端に水平方向の力を加えて 破壊させたときの強度（この大きさはJISの規定にはな い）は，700～ $800 \mathrm{kgf}$ 程度であった。凍上性の材料で埋 戻したときの凍結土圧はこのトラフの強度をはるかに越 えており，トラフの強度を増して凍結土圧に抵抗させる ことよりも，まず凍結土圧を減少させるための対策を施 すのが妥当であろう.

このトラフは最大縮み量が 1 〜 $\mathrm{mm}$ 程度になると 微小クラックの発生が見受けられた. 実験終了後に掘り 起こして調べたいくつかの結果によれば，クラックはほ とんど例外なく底盤の下面にトラフの長手方向に入って いた。 また現場で実用に供されているトラフの凍上被害 調査においても，クラックの発生は，一部で側壁にもみ られたが，ほとんどは本実験の場合と同様に底盤におい て発生していた.
一方，持上がり量についてみると，傾向としては基礎 砂利を設けない場合に大きくなっていることがわかる. トラフが押しつぶされることも，持ち上げられることも ともに周辺地盤の凍上によってもたらされることである が，前者には側壁背面の裏込め処理の効果があるが，後 者の持上がりには底盤下への基礎砂利の設置の効果があ るようである。

\section{4. 結 論}

試験設置したトラフについて，冬季間の地盤凍結に 伴って側壁に加わる凍結土圧や変形(側壁間隔の縮み量) などの測定を行った結果を述べてきた，主な内容をまと めると，次のようになる。

（1）トラフでは, 背面土の凍結線が傾いて入るため, その結果としてトラフを破壊させるような凍結土圧の水 平成分が現われる。

（2）トラフの変形を拘束した状態で側壁に加わる凍 結土圧は，気温の変化に刻々と対応する短期的な変動を 伴いながら，シーズンを通して変化していく.

（3）縮みを拘束しない状態では，（2 ）の力に対応し た形で縮みが発生する。

（4）適切な背面処理を施していないトラフでは，そ の強さをはるかに上回る凍結土圧が発生する。

（5）発生する凍結土圧あるいは縮みの大きさは，背 面土表面の形状に大きく影響される.

（6）難凍上性の材料で裏込めをしたり，断熱材を用 いたりする対策工法の効果は明らかに認められる。

（7）側壁に加わる凍結土圧の大きさや，トラフの変 形量は，凍結線における凍上力や変位だけでなく，それ らを伝える凍土の挙動や未凍土の圧縮性などが複雑に影 響してくる。

今回の実験を通して，トラフ側壁に加わる凍結土圧が 発生するメカニズム，凍結土圧の大きさあるいはトラフ の変形の現われ方，および，いくつかの対策工法の効果 などの基礎的なところはかなり明らかにすることができ た. 現在，難凍上性材料による裏込めによる対策工法を 中心として，その効果を定量的にとらえて，設計に役立 つデータとするための実験を継続している.

最後に，本研究を進めるにあたり，多大なご協力をい ただいた北海道網走土木現業所, 網走地方コンクリート 製品協同組合，中神土木設計事務所の関係者に感謝の意 を表わします。

\section{参 考 文 献}

1）土質工学会編：土の凍結一その制御と応用一，土質基礎 工学ライブラリー23, pp. 91〜 154, 1982.

2）真井耕象：凍上被害とその対策について, 土と基礎, Vol 
1 , No. 1 , pp. $7 \sim 13,1953$.

3）青山清道 - 福田 誠・杉内祥泰 - 小野泰彦 - 池田 格： 用水路の凍上被害に関する一考察, 土質工学研究発表会, pp. 889 890, 1987.

4）池田一賢：鉄筋コンクリートトラフの凍上被害につい て, 北海道土木技術研究発表会, pp. 120 139, 1985 .

5）森井 徹 - 津田 進 - 高橋英紀 - 長沢徽明 : 凍結期にお ける水路側壁の挙動, 農業土木学会誌, 第 45 巻, 第 9 号, pp. 615 619, 1977.

6) 吉田重一・高田健治：寒冷地における用水路の構造設計, 農業土木学会誌, 第 48 巻, 第 7 号, pp. $471 \sim 477,1979$.

7）木下誠一編：凍土の物理学, 森北出版, pp. 104, 1982.

8) Loch, J.P.G. and Miller, R.D. : Tests of the concept of secondary frost heaving, SIL Sci. Soc. Amer. Proc., Vol. 39, pp. 1036 1041, 1975.

9）高志 勤・生頼孝博 - 山本英夫：土の間隙水の粘性増加
による凍上抑制に関する実験的研究, 土木学会論文報告 集, 第 298 号, pp. 77 85, 1980.

10）たとえば，木下誠一：凍土の一軸圧縮クリープ, 低温科 学, 物理編, 第 31 輯, pp. 261 269, 1972.

11）木下誠一：凍上力実験, 低温科学, 物理編, 第 30 輯, pp. 191 201, 1971.

12）高志 勤 - 生頼孝博 - 山本英夫 - 岡本 純 : 土の最大凍 上力に関する実験的研究, 雪水, 第 43 巻, 第 2 号, pp. 207 216, 1981.

13）福田 誠・小川正二・亀井健史：Segregation Potential 理論による原位置凍上量予測，土木学会論文集，第 400 号 /III-10, pp. 253 259, 1988.

14）榎戸源則：土丹の凍結圧測定実験, 土と基礎, Vol. 25, No. 7, pp. 33 39, 1977.

(1989.7.28 • 受付) 